\title{
Developments in Revenge, Justice and Rape in the Cinema
}

\author{
Peter W. G. Robson ${ }^{1}$ \\ Published online: 5 March 2019 \\ (C) The Author(s) 2019
}

\begin{abstract}
The index to the 2018 VideoHound Guide to Films suggests that under the broad heading of "revenge" there have been something in excess of 1000 films. This appears to be the largest category in this comprehensive guide and suggests that this is, indeed, a theme which permeates the most influential sector of popular culture. These films range from influential and lauded films with major directors and stars like John Ford (The Searchers (1956) and Alejandro González Iñárritu (The Revenant (2015)) to "straight to video" gorefests with little artistic merit and a specific target audience (The Hills Have Eyes (1977)). There is, as the Film Guide numbers suggest much in between like Straw Dogs (1972) and Outrage (1993). The making and re-making of "revenge" films continues with contributions in 2018 from such major stars as Denzel Washington in The Equalizer 2 and Brue Willis in Death Wish. Within this body of film is a roster of films which allow us to speculate on the nature of the legal system and what individual and to a lesser extent community responses are likely where there appears to be a deficit of justice. One of the sub-groups within the revenge roster is a set of films which focus on revenge by the victim for rape which are discussed for their rather different approach to the issue of justice. Most unusually, the award winning film Elle (2016) has been described as a "rape revenge comedy". Given the thriving nature of the overall sub-genre this causes pause for thought and justifies a closer look at what seems unlikely in an era of enhanced awareness of the trauma and damage of this kind of brutal criminality. This essay seeks to examine this film and locate it within the wider world of revenge films, notions of justice and assess it in context.
\end{abstract}

Keywords Revenge films $\cdot$ Vengeance $\cdot$ Vigilante $\cdot$ Rape revenge

Peter W. G. Robson

peter.robson@strath.ac.uk

1 School of Law, University of Strathclyde, Glasgow, Scotland 


\section{Revenge, Justice and the Law}

The principal interest, then, here is on those films which cast some light on the relationship between the seeking of justice and the act/s of vengeance-the interface between the legal process and justice. For instance, Cape Fear ${ }^{1}$ and its remake, provide a fascinating contrast between what we might term "simple revenge" and "principled revenge". The film-maker, Martin Scorsese, altered the original story of the resentful ex-convict Max Cady seeking revenge on the lawyer who had been the witness at his trial. In the later version we see that the system, in the form of that lawyer had denied him a fair trial. His revenge has a rationale rather than merely being an act of spite and anger as the first film showed. Changing Lanes, ${ }^{2}$ by contrast, features a conflict between a lawyer and an insurance salesman who have a minor collision in their cars. They are both are on their way to separate crucial appearances in court cases. The lawyer just wants to buy his way out of any trouble as lawyers do. $\mathrm{He}$ is, however, taken to be disrespecting the other motorist who is anxious to "go by the book". He perceives ignoring legal niceties might harm his standing before the court where he is seeking custody rights in relation to his children. Things spiral out of control with increasingly serious acts revenge after this perceived slight out of all proportion to the original misunderstanding.

The kinds of triggers to actions of revenge range from physical attacks on the victim or a member of their family ${ }^{3}$ and bullying ${ }^{4}$ to hurt feelings by someone ending a relationship. ${ }^{5}$ The victims are usually those directly involved in causing the perceived harm ${ }^{6}$ or someone taken to represent institutional harm. ${ }^{7}$ Vengeance, in order to comply with the prohibition of showing revenge under the Production Code, ${ }^{8}$ was perforce at the core of many westerns from High Plains Drifter ${ }^{9}$ to Django Unchained. ${ }^{10}$ In the former a mysterious stranger takes revenge on the townsfolk who allowed the death of their previous Marshall, Jim Duncan. This includes an episode in which part of the revenge involves rape as part of the price one of townswomen must pay on behalf of the town. In the latter, the bloody revenge is on a

\footnotetext{
1962 (dir J Lee Thompson).

2002 (dir Roger Michell).

3 Cloudburst (1951) (dir Francis Searle)—revenge for wife's accidental death; Kill Bill (2003) (dir Quentin Tarantino) and Kill Bill II (2004) (dir Quentin Tarantino) where the bride avenges the men who killed her husband and attempted to kill her on her wedding day; Closure (2007) (dir Dan Reed)— revenge for attack by gang.

${ }^{4}$ Carrie (1976) (Brian de Palma) - revenge of the bullied.

5 Fatal Attraction (1987) (Adrian Lynn)—revenge of the spurned lover; The Coalition (2013) (dir Monica Mingo—revenge of four women for being jilted.

${ }^{6}$ Cape Fear (1961) - revenge on a lawyer and his family for being a witness at the revenger's trial; Cape Fear (1991) — revenge on a lawyer and his family for burying documents indicating the victim had a sexual history.

7 Calvary (2013) a parish priest executed for the paedophile acts of fellow priests with which he has no connection in time or place other than his being a Roman Catholic priest.

8 see below at fn 28.

91973 (dir Clint Eastwood).

102012 (dir Quentin Tarantino).
} 
former slave owner by his ex-slave whose wife has been taken too. The notion of revenge as operating both under the law and outwith its formalities is encountered in True Grit. Here the protagonist, the young Mattie Ross seeks to bring her father's killer to justice to face trial. She describes it, though, in terms of an act of revenge.

People do not give it credence that a fourteen-year-old girl could leave home and go off in the wintertime to avenge her father's blood but it did not seem so strange then, although I will say it did not happen every day ${ }^{11}$

These themes of revenge are not confined to the cinema of Hollywood but are encountered in the work of other major film producers. In Europe from films by major directors like Ingmar Bergman ${ }^{12}$ and modern "blockbusters", ${ }^{13}$ to French cinema ${ }^{14}$ the vengeance trope is encountered. More recent developments in the new cinema industries have also seen revenge featuring with notable contributions from the Japanese ${ }^{15}$ and South Korean film industries. ${ }^{16}$ Revenge has also been a theme of black comedies ranging from Kind Hearts and Coronets $^{17}$ to the most recent version in The Dressmaker. ${ }^{18}$ What unites these distinct offerings is the impetus for revenge. This has its source in the treatment of a woman by a community drawing on a hypocritical and cruel stance centred on class and a narrow morality. Whilst hugely popular and entertaining, the comedic approaches have less to tell us about the interface between the nature of the legal process and its relationship to justice.

A major trope within the vengeance roster are those films which centre on revenge for wrongs visited on family or friends which goes unpunished-but where the protagonist knows the perpetrator. ${ }^{19}$ This has been the most consistent theme pursued by filmmakers over the last 40 years in the form of the vigilante film. ${ }^{20}$ This is of particular interest to scholars of the justice system since it throws light on how law commands and loses respect and the resultant problems when the system

11 Portis, Charles (1968) True Grit (London Bloomsbury) at 9.

12 The Virgin Spring (1960) (dir Ingmar Bergman) - revenge of rape and murder of daughter.

13 The Girl with the Dragon Tattoo (2007) (dir Niels Arden Oplev)_revenge by victim of rape; John Wick (2014) (dir Chad Stahelski and David Leitch)—revenge for killing of a puppy-a present from the protagonist's late wife.

${ }^{14}$ Les Diaboliques (1955) (dir Henri-George Clouzot)—revenge on exploiter-to The Bride Wore Black (1968) (Francois Truffaut)—revenge of the five murderers of her husband on their wedding day.

15 Lady Snowblood (1973) (dir Toshiya Fuijita) — child born in prison avenges the murder of her father by a gang of criminals beyond the reach of the law.

16 The Housemaid (1960) (dir Ki-young Kim)—see also the Revenge Trilogy of Park Chan-wook (Sympathy for Mr Vengeance (2002)—revenge for death of daughter, Oldboy (2003)—revenge for unknown actions_-and Sympathy for Lady Vengeance (2005)—engineering the death of the child murderer who framed her.

171949 (dir Robert Hamer).

182015 (dir Jocelyn Moorhouse).

19 In the Bedroom (2001) (dir Todd Field) in which a mild small town couple take the killer of their son and murder him leaving no evidence after finding the legal process compromised; also Tarantino's Death Proof (2007) — revenge by women on a murderer.

${ }^{20}$ Robson P (2016) Beyond the Courtroom: Vigilantism, Revenge and Rape-Revenge Films in the Cinema of Justice (in Picart C, Jacobsen M and Greek C eds) Framing Law and Crime (Lanham, Maryland; Fairleigh Dickinson University Press) pp 165-200—on which this section draws. 
is perceived not to be working. As one of the film posters puts the matter "What do you do when justice fails". ${ }^{21}$ The answer over the 45 years since the 1970s for the victim of crime is to respond on a one-off basis to eliminate the evil which the legal system is unable or unwilling to process effectively. This is a very particular individualist approach which eschews any kind of broader political analysis beyond a distrust of government's viability. It is a relatively recent but a persistent trope within mainstream film-making. The reasons are partly to do with censorship as we shall see.

\section{Revenge and the Individual}

The Motion Pictures Producers and Distributors of America (MPPDA), which later became the Motion Picture Association of America (MPAA), adopted a code on 31st March 1930, began enforcing it in 1934, and abandoned it in 1968, in favour of the subsequent MPAA film rating system. ${ }^{22}$ This industry voluntary self-regulation, known as the Hays Code, sought to protect the viewing public in the United States, and by extension, much of the rest of the world, from what were seen as various malign influences-sex, sacrilege and socialism as well as miscegenation. These were the principal targets identified in the years between 1930 and the late 1960s. These were the years when the Code and equivalents elsewhere were in full vigour. ${ }^{23}$ Amongst the issues which the Code frowned on was the belittling of the legal process and any film where the perpetrator of illegal acts did not get their just desserts. The general principles included the statement that

Law shall not be ridiculed nor shall sympathy be shown for its violation

This was discussed in greater detail

Crimes Against the Law These shall never be presented in such a way as to throw sympathy with the crime as against law and justice or to inspire others

with a desire for imitation.

Specifically any film where revenge was the theme was forbidden

c. Revenge in modern times shall not be justified.

This was to be subject to some leeway covering the absence of civilisation or the rule of law

\footnotetext{
${ }^{21}$ Eye for an Eye (1995) (dir John Schlesinger).

${ }^{22}$ Original version available at https://www.asu.edu/courses/fms200s/total-readings/MotionPicturePr oductionCode.pdf (last consulted 5 October 2018).

${ }^{23}$ Sperling, Millner, and Warner (1998) Hollywood Be Thy Name (Roseville California, Prima Publishing) and Robertson, James (1989) The Hidden Cinema: British Film Censorship in Action 19131975 (London, Routledge).
} 
Revenge in modern times shall not be justified. In lands and ages of less developed civilization and moral principles, revenge may sometimes be presented. This would be the case especially in places where no law exists to cover the crime because of which revenge is committed.

As indicated this did not preclude the theme of revenge in the historical past and was, as was noted, typically encountered in Westerns. The lone stranger coming into clean up the corruption and dominance of powerful interests in a semi-lawless town is a theme we encounter time and again from Dodge City ${ }^{24}$ to Shane. ${ }^{25}$

\section{a. The Essence of Individual Revenge-the Vigilante}

After the decline of the Code, vigilantism has flourished in film. The quintessential modern revenging vigilante has been the character of Paul Kersey, played with world weary resignation by the actor Charles Bronson. We are talking about the normal citizen, who if left alone by criminal elements would have no reason to strike back. The simple revenge theme has cropped up in a whole series of films where the original perpetrators are shown as having no redeeming qualities. Their crimes are done seemingly almost for sport as in Sudden Impact (1983), Eye for an Eye (1995) and The Limey (1999). Here the vigilante seeks to deal directly with a perpetrator whom the legal system has failed to bring to justice. The twentyfirst century also has its variants on this theme in the first decade with The Brave One (2007), Gran Torino (2009), Law Abiding Citizen (2009) and Harry Brown (2009). More recently, in the second decade of the century, we have standard lone vigilantes making their appearance in Seeking Justice (2012), Vendetta (2013), John Doe: Vigilante (2014), John Wick (2014), A Walk among the Tombstones (2014), The Equalizer (2014), and in 2018 The Equalizer 2 and a remake of Death Wish.

The term vigilante is also sometimes bestowed on Government operative agents "on the edge". Those operating loosely as agents of the Government like John Rambo (First Blood 1985; Rambo: First Blood Part II 1985; Rambo III 1988) but with a cavalier disregard for procedure are not really vigilantes any more than the Government spy James Bond, or special operative John McClane in the Die Hard franchise from 1988 onwards. These are in strict terms simply servants of society who are boldly going where others fear to tread in protecting the status quo and the lawfully constituted authorities rather than ignoring or bypassing the law. ${ }^{26}$ They are suspicious of due process and the inevitable paperwork of arrest.

\footnotetext{
241939 (dir Michael Curtiz).

251953 (dir George Stevens).

26 See Robson (2016) on disaffected and corner cutting state officials who actually work within the legal framework rather than outside but are often referred to as "vigilantes".
} 


\section{b. The Creation of "Legality" and the "Collectivist Vigilante"}

One of the reasons why the Hays Code made a distinction between modern revenge and the historical versions has to do with the recent emergence of the link between law and democracy. There is a shift from random lawlessness and individual responses and the emergence of official local law enforcement officers representing the community rather than protecting the interests of the rich. This is the very essence of the Western genre. Hence, versions of group action also crop up in a way which is akin to lone vigilantism. The Revengers (1972) is an example along with The Magnificent Seven (1960). Here we move into the replacement of random lawlessness and individual response to it, to a community perspective. In time, as The Man Who Shot Liberty Valance (1959) demonstrates, the lawyer turned politician, Ranse Stoddard replaces the frontier gunslinger Tom Doniphon. The dystopian nightmare of Mad Max (1980) and Mad Max: Beyond Thunderdome (1985) is where, in a post-Apocalyptic future, we return to this reliance on the individual in place of consensus-based law enforcement on behalf of the community.

The introduction of the formality of the law places the individual justice figure into an ambivalent position in relation to the procedures and processes of law enforcement. Hence, like the Hays Code, we can see the moral protagonists in Shane (1953) and in Hannie Caulder (1971) not as vigilantes but as proto-law officers. In the modern world, the reverse could be said to be appearing. In the Western, in The Man Who Shot Liberty Valance (1959), the random gun justice of Tom Doniphon was replaced by the legislature and state-sanctioned equally deadly enforcement of Ranse Stoddart. In the modern cinematic world, the challenge to the inadequacy of lawful policing comes from a series of individuals seeking solutions on an ad hoc basis in the person of vigilantes like Paul Kersey, Karen McCann and Erica Bain. This has had a resonance for filmmakers which collectivist actions by the likes of the Gulabi Gang in India and Los Justicieros de la Tierra in Mexico have not enjoyed thus far in popular culture.

\section{c. The Modern Vigilante Revenge Film Assessed}

The essence of the modern vigilante revenge film is to pose questions about the nature of justice in a much clearer way than occurs in, say, the traditional courtroom drama but in the context of a thriller. What we get is the revenge motif with a family context. The vigilante focus tends to have more time devoted to moral conundrums and ambiguities than we find in the run-of the-mill trial movie. The courtroom dramas may also contain thriller elements but tend to be centred on the skill, inadequacy or personal crisis of the major lawyer protagonist. The moral centre is often not in dispute-is the accused actually innocent of the crime? How will the legal team for the "David" side manage to overcome the obstacles they face? How will they establish that there is evidence to exculpate their client or to prove that the other side has breached their duties, for instance, not to pollute as in, for instance, $A$ Civil Action (1999) or Erin Brockovich (2000). ${ }^{27}$

${ }^{27}$ Greenfield S, Osborn G and Robson P Film and the Law (2010) (Oxford, Hart). 
Vigilante revenge films, by contrast, are about what ordinary citizens do when the justice system does not meet their expectations and fails them. "Justice" requires there to be revenge. The perpetrator whom the legal system has let slip through its fingers must be punished. The extent and level of debate about these complex moral dilemmas is variable. Some films return to the theme whilst others simply use the notion of "justice denied" as the catalyst for a thriller. This section focuses on the films which have been most successful in terms of box office, which have major stars and where a recognized director is involved. There are many other films with a vigilante element or where the same kinds of themes appear and a full overview of the area would permit total coverage. In fairness, many of these are concerned with system challenges rather than simply individuals. The major films discussed here are representative of the other lesser films. We now look at the consistent features and tropes which can be seen in the most important films in this sub-genre of thrillers that centre around a question at the heart of the justice system when wrongdoing is met with extra-legal force. This is encapsulated in the question posed on the poster advertising the film The Brave One (2007): "How Many Wrongs to Make it Right"?" Once Paul Kersey or Erica Bain go beyond their own individual justice failure and start to root out the "cancer" of other unpunished characters in society where does it end? $?^{28}$

Where the revenge is undertaken by an amateur they normally manage to outwit the perpetrator whether or not it is museum administrator, Karen McCann (Eye for an Eye 1995), civil servant Jack Elgin (The Fourth Angel 2002) or radio programme maker Erica Bain (The Brave One 2007). They may turn out to have hidden abilities as a killer or be drawing on their hitherto hidden past. In Law Abiding Citizen (2009) Gerard Butler's Clyde Shelton is revealed to have been a Government operative whilst Michael Caine's pensioner Harry Brown (2009) has been a Marine and gets out his old knife and obtains a weapon. Denzel Washington's Robert McCall has been involved in dark ops for the Government in The Equalizer (2014) as have been Danny Dyer's Special Ops interrogation specialist, Jimmy Vickers, in Vendetta (2013) and Keanu Reeves' eponymous John Wick (2014). The perpetrators are brought down to earth in bloody confrontation. There is no opportunity for them to reflect on their past actions and to repent. Vengeance is exacted in a range of bloody ways. Sometimes these are appropriate to the nature of the original crime as in the burning alive of the gang leader in Vendetta (2013) but this is more a feature of the rape-revenge roster discussed below.

There is a brief moment for reflection after the elimination of the "evil". This "final scene" is one which seems to valorise the revenge actions of the vigilante and has been described as "pro gun propaganda". ${ }^{29}$ The vigilante escapes the wrath of the law. There is in many instances connivance by the representatives of the forces of law and order to ensure that the vigilante escapes any punishment for their actions-from Paul Kersey, through Karen McCann and Erica Bain to Jack Elgin

\footnotetext{
${ }^{28}$ For a discussion of the structure of vigilante films see Robson (2016).

${ }^{29}$ Sharf, Zack (March 5, 2018). "Eli Roth Defends 'Death Wish' Remake by Claiming It's 'Not ProGun' and Comparing it to 'Get Out'". IndieWire.
} 
and Harry Brown we are left to cheer the moral actions of the vigilante. Not only have they had their revenge on the perpetrator but they have been allowed to return to their normal proper law-abiding lives. This ranges from simply surviving to live another day (Eye for an Eye 1995, Outlaw 2007 and Harry Brown 2009), sunning oneself on a yacht (The Fourth Angel 2002) or taking up the role of vigilante in a new location (Death Wish 1974; Vendetta 2013). Vigilantism by part-time amateurs works. The only vigilantes who pay for their actions, and die, are the ones for whom life is already effectively over-physically with terminal cancer (Gran Torino 2009) or psychologically with suicide (Dead Man Shoes 2004) or at worst the ending is ambivalent (Death Sentence 2007).

\section{d. The Revenge Dilemma in the Vigilante Film}

The advantage the vigilante film has over the traditional courtroom drama is the ability for it to be set firmly and credibly within the action movie genre. There is extensive use of chases and action sequences. This is not the land of suits, strategies and gavels. Here we have tension heightening music and short "bite—sized" discussions of the morality of acting or not acting. It does not involve an extended reflection on the human condition which we find in, for instance, Judgment at Nuremberg (1961) or A Man for All Seasons (1966) but it does have recognisable bad characters against whom the "reasonable" citizen might want to act. The revenge reflex is to an extent intellectualised and the nature of justice and its source assessed. There is even in the final shot of Seeking Justice/Justice (2012) a suggestion that a form of vigilantism could subvert the whole legal process with widespread vigilante actions being operated through a shadowy Matrix-like underground. ${ }^{30}$

These vigilante films are standard mainstream fare available in today's multiplexes. The directors of these vigilante films were also major figures like John Schlesinger, Steven Soderbergh, Shane Meadows, Michael Winner and Neil Jordan. These are directors whose work has been recognised both at Film Festivals and at Award Ceremonies as well as achieving major box office success. The films had in the past and continue to attract such "A list" stars as Clint Eastwood, Jodie Foster, Kevin Bacon, Sally Field, Samuel L. Jackson, Michael Caine, Gerard Butler, Jamie Foxx, Nicolas Cage, Guy Pearce, Liam Neeson, Keanu Reeves, Denzel Washington and Bruce Willis as well as others with solid box office track records like Chuck Norris, Sean Bean and Danny Dyer. There is a consistent roster of films over the past 45 years which focus on films which show that the system cannot cope and that the only approach is to settle accounts outwith the formal justice system. These films

\footnotetext{
30 The mild reluctant avenging victim Nicolas Cage is given a codeword to know that he is amongst those who offer mutual aid and carry out revenge attacks in the style of Hitchcock's Strangers on a Train (1951) where unconnected people "swap" victims. He is required to kill a sex offender which he only manages to do by accident. He is arrested for murder but released when he is invited to complete the code phrase of the organisation "The Hungry Rabbit Jumps". Everyone it seems is involved. The victim whose death he caused turns out to have been a reporter investigating vigilantes. A complicated story of blackmail unfolds at the end of which it seems vigilantism pervades the whole of the justice system.
} 
start with Death Wish (1974)_ “the original vigilante" ${ }^{31}$ and can be seen in a range of individual revenge plots mentioned above. ${ }^{32}$

This, then, is an identifiable genre leading to homages and the like. Some of the films with vigilante themes provide these with a twist. In Hot Fuzz (2007) a quiet peaceful crime-free town turns out to be the result, not of a good mix of effective policing and good citizens but of unbridled vigilantism by a group of disaffected senior citizens eager to keep the town free from rowdies and misfits. In Hero Wanted (2008) an apparent victim vows revenge on the perpetrators of the bank robbery which left an innocent bank clerk dead. All is, however not as it seems. He himself actually "set up" the robbery to have the chance to impress the young female bank clerk by foiling his friends. The girl whom he was striving to impress ended up killed by accident. Finally, in Gran Torino (2009), a xenophobe stands up for a group of incomers with whom he appears to have no common ties or interests. Again a twist confounds our expectations when we expect a serious culmination of evil confronted in a shoot-out. In a similar situation, although seriously outnumbered Butch and Sundance gun down their opponents in Butch Cassidy and the Sundance Kid (1969). This is parodied in a scene from Blazing Saddles (1974) where the Ringo Kid singlehandedly shoots the guns from the hands of all 8 of his opponents. Still expecting something on these lines and drawn in by the poster advertising the film showing Clint Eastwood with rifle in hand, we get instead the ending from Butch Cassidy minus the truth-denying freeze-frame. Eastwood, the hero of Spaghetti Westerns, Pale Rider (1985) and Unforgiven (1992) is, in Gran Torino (2009) cut down in a hail of bullets reaching, not for a gun, but for his cigarette lighter. The police arrive and the gang goes down for his murder. He has shown that there is another way. In the process he has sacrificed himself but we recall his coughing blood into his handkerchief and realise he had only a short time to live. It seems to be a wry undercutting of the simplistic appeal of the revenge of vigilantism. This chimes in with an earlier film directed by Eastwood, Mystic River (2003). Here the issue of the perils of vigilante justice was also subtly raised with a group of successful avengers suffering in a variety of ways and calling into question the whole revenge approach. As Miller suggested in his analysis of Eastwood's earlier revenge work, "revenge is perceived as a reform of the law, not a revolution displacing it". ${ }^{33}$

The cinema is suffused then with themes of random stranger violence not reflected in crime surveys and statistics where those whom we should fear are members of our family, friends and acquaintances. These are allied to media themes of the routine malfunctioning of the justice system. Files are lost. The rules obstruct

\footnotetext{
31 Advertising strap line on the DVD cover.

32 This roster covers An Eye for an Eye (1981); Eye for an Eye (1995); The Limey (1999); The Fourth Angel (2002); Dead Man's Shoes (2004); Red (2004); Death Sentence (2006); The Brave One (2007); Outlaw (2007); Gran Torino (2009); Law Abiding Citizen (2009); Harry Brown (2009); Seeking Justice (2012); Vendetta (2013); John Doe: Vigilante (2014); John Wick (2014) A Walk among the Tombstones (2014), The Equalizer (2014) The Equalizer 2 (2018) and Death Wish (2018).

${ }^{33}$ Miller, W (1998) Clint Eastwood and Equity: The virtues of revenge and the Shortcomings of Law in Popular Culture (in Sarat A and Kearns T Law in the Domains of Culture (Ann Arbor; University of Michigan Press).
} 
the way of "true justice" with public prosecutors and judges being obsessed with elaborate rules on what amounts to illegal search and seizure. The narrative conventions of the films are simple. The State has failed an ordinary, identifiable sympathetic character whose life we know something about. There is a family. Their happiness has been brought to a jarring halt. Justice is denied to them and if the ordinary citizen cannot get justice what is to be done? The answer from vigilante cinema is to "take back the night". The clear inference from these films briefly surveyed is that revenge as an option "works". The common final scene in the range of vigilante films is that justice has been effected informally and the world continues. Our vigilante or justiciero has done what had to be done and the world can return to an even keel. It is little wonder that the 2nd amendment to the United States Constitution has so many adherents since not only is there ever-present "stranger danger" but a strong chance that in order for this to be dealt with the individual will have to seize the hour. Life can then go on but the "evil" is no more.

There is an interesting development to observe for those looking at the film vigilante in the second decade of the twentyfirst century. We have a continuing preoccupation with the fictional urban vigilante. There has also been a novel approach in the marketing of the Australian film John Doe: Vigilante (2014). This premiered in March 2014 and at one level is absolutely standard fare. To quote from the publicity from the producers of the film at that time

Some call him a hero. Some call him a villain. He's "John Doe: Vigilante"an ordinary man who decides to take the law into his own hands. Frustrated with a failing legal system that continues to allow violent criminals to go free, John Doe begins exacting justice the only way he knows how-by killing one criminal at a time. Soon he becomes a media sensation and inspires a group of copycat vigilantes, but who is the real John Doe-a pillar of justice or a coldblooded murderer? You decide. (Main Street Films)

In what was described as "innovative marketing ploy" the producers of the film launched a free interactive game Vigilante: Speak for the Dead. This was part of a campaign to publicise the film. To do this the producers explained that it enabled users to take the role of a vigilante and disarm other players while also forming powerful vigilante 'Crews'. It poses questions such as: What's your idea of justice? Will you steer clear of killing and only target hardened criminals? Or are you a psychotic killer, waxing $j$-walkers and spending drivers? This marks a recognition by those producing this films that such films have an impact on audiences beyond the time spent watching the action.

\section{Rape Revenge Films}

Alison Young and others also look at the theme of revenge, though with a very different eye. She looks not at the affected family member reaction to trauma but 
at the surviving victim's response in her discussion of rape-revenge films. ${ }^{34}$ This discussion is located within what is a recognisable sub-genre. What she is talking about and examining is a scenario where there is violent revenge by the victim of "a shocking scene of gang rape". ${ }^{35}$ This will be "followed by a succession of episodes of violent retribution ..... after the victim, perhaps having sought legal assistance or the intervention of the police or equally having decided that no effective institutional assistance will be forthcoming decides to undertake the task of revenge". 36 Here, then, is an alternative version of the vigilante film also involving revenge and operating outwith the law. The starting point, however, is different. This focus is narrower. Here we have a situation where "the agency of the victim can bring about justice in some form or other". ${ }^{37}$ Young's principal concern is that the depiction of rape in these films is exploitative and unacceptable and it is possible that "the depiction of sexual violence be imagined differently". ${ }^{38}$ We should "refuse the invitation to look at the crime image of rape". ${ }^{39}$ This reflects Young's desire to move beyond the focus in some law and film scholarship on narrative tropes. Her preoccupations are with the aesthetics of film and the process of spectatorship. Her notion that the portrayal of rape has pandered to the prurient and should be rejected seems to be entirely well put. The scenes in the films she discusses are evidence that, given an opportunity, filmmakers will dwell on the rape in a way that needs to be addressed.

There is extensive common ground between rape-revenge films and those films in which those indirectly affected by stranger violence to family members seek justice. There is a considerable body of films produced over the years which share the themes Young draws attention to. These are, however, films which are limited in their audience reach. From the very beginning with what Young refers to as the first film in the genre in 1978, I Spit on Your Grave ${ }^{40}$ there is a succession of films which are highly violent "gorefests" with prominent coverage of the rape element of the narrative. Over fifty such films are noted in the rape-revenge literature. ${ }^{41}$ There are occasional exceptions with some mainstream offerings like Sleepers (1996). Although the victims of abuse by prison guards are boys in the criminal justice system the nature of their abuse is hinted at rather than made explicit here. It has also

\footnotetext{
34 Young, Alison (2010) The Scene of Violence (Abingdon, Oxon, and New York; Routledge) Chapter 3 .

35 Young loc cit 44.

36 ibid.

37 Young loc cit 66.

38 Young loc cit 73.

39 ibid.

40 The earlier Last House on the Left (1972) is on the same lines involving rape and revenge, but by the victim's parents and is so identified by Read (2000) at 41-an updating of the story of Bergman's Virgin Spring (1960).

41 Read, Jacinda (2000) The new avengers: feminism, femininity and the rape-revenge cycle (Manchester and New York; Manchester University Press); Heller-Nicholas, Alexandra (2011) Rape-Revenge Films: a critical study (Jefferson, North Carolina and London; McFarland and Co); Henry, Claire (2014) Revisionist Rape-Revenge: Redefining a Film Genre (New York, Palgrave Macmillan); see also Hephaestus Books (2011) Rape and Revenge Films (Hephaestus Books-no publishing details on the book number ISBN-13: 9781242972744)—it is a collection of internet articles.
} 
been suggested that The Girl with the Dragon Tattoo (2009) comes within the genre although we merely hear of the rape rather than it being shown. ${ }^{42}$ There are also art-house products like Irréversible (2002) but the majority are for the DVD market with low production values and lacking any noted actors or directors. For the most part they focus on the revenge as revenge without any concern for the consequences for the revenger and with minimal focus on the post revenge period. Such is the construction of their plots, their characterisation and their dénouements that their likelihood of contributing to any debate about film's influence on the portrayal of the justice system seems limited. They are, nonetheless, pertinent to discussions of vengeance and its relationship to the justice system.

The films are largely obscure and well away from the multiplex fare of the vigilante films discussed above. I Spit on Your Grave (1978) is described in one of the Film Guides as a film "worth zero as a film; lots of violent terror and gory death; totally irresponsibly portrayed" 43 as well as being described by Henry as a "B movie". ${ }^{44}$ It did not receive a cinematic release in Britain and went straight to video/ DVD. Its 2010 remake treads the same path and went straight to DVD. What happens to the victim Jennifer Hills once she has killed the gang of rapists, one by one, we do not know. The film closes on her final act of revenge in both versions. Her relationship to the justice system remains unresolved. Whether or not she will suffer the fate of Aileen Wournos in Monster (2007) or that of Karen McCann in Eye for an Eye (1995) we can only wonder. This is the crucial difference in the focus between the vigilante films examined and the rape-revenge films which share the revenge element. The first set involves an ambivalent and shifting stance in relation to the justice system whilst the latter proceed on the assumption that it is useless and irrelevant.

Responding to Clover's work on the alleged pleasures of horror films, ${ }^{45} \mathrm{Read}$ addresses the issue of agency within the rape-revenge genre. ${ }^{46}$ She sees such films as transforming the victim into heroine. ${ }^{47}$ Given the dominant nature of the sexploitation trope in such films, whether these films can be seen as a way of making sense of feminism, as Read suggests, ${ }^{48}$ seems questionable. The rape-revenge film is not limited to the United States. Heller-Nicholas documents the production of such films across different cultures and across different genres. ${ }^{49}$ She demonstrates that the underlying themes of rape-revenge go well beyond Anglophone cinema and can also be encountered in Argentina, Australia, Canada, France, Germany, Hong Kong, India, Japan, Spain and Turkey. ${ }^{50}$ The existence of the rape-revenge theme is also

\footnotetext{
${ }^{42}$ Heller-Nicholas (2011) 172.

43 VideoHound 2008 467; VideoHound 2005513.

44 Henry (2014) 15.

45 Clover, C (1992) Men, Women and Chain Saws: Gender in the Modern Horror Film (Princeton, Princeton University Press).

46 Read (2000).

47 Read op cit at 8.

48 Read op cit at 10.

49 Heller-Nicholas (2011) Chapters 2 and 3.

${ }^{50}$ Heller-Nicholas loc cit Chapter 3.
} 
shown to exist across genres appearing in Westerns and horror films. ${ }^{51}$ Her focus, though, as she explains, is to explore a "broader cultural confusion about rape generally" reflected in the way in which rape has been screened and to examine "simplistic assumptions about the ethics of rape and its representation on screen". 52 As indicated, that is not the focus of the current paper, although I would certainly concur with Heller-Nicholas's assessment that "many of the female-centred rape-revenge films.... addressed in this book are undeniably sensational attempts to profit from the ugly desire to watch sexual violence". ${ }^{53}$ Henry, for her part, is concerned with highlighting "affective response and ethical engagement" in her study. ${ }^{54}$ She looks at the rape-revenge films with a focus on genre and suggests that more recently a revisionist version of the rape-revenge film has emerged. These have a more ambivalent relationship to violent revenge. She cites the role of Adam in Straightheads (2007). ${ }^{55}$ She also contrasts the more recent work such as Twilight Portrait (2011) and Katalin Vargas (2009) with Lipstick (1976) to make this point. ${ }^{56}$ Again all the modern films are far from the mainstream and subject to the same concerns as "the classics". Revenge there certainly is. Contemplation and reflection are absent. So unsympathetic are the perpetrators and so heinous their crimes that the revenge reaction is portrayed as the only option. Given the nature of rape statistics and the likely source it is to be regretted that these more common domestic experiences do not achieve more extensive, sensitive and sympathetic coverage. ${ }^{57}$

\section{a. Changing the Tone?}

Although a number of serious scholarly analyses have been published in this area, my own view hitherto has been that the vast majority of these were aimed at the "dirty mac brigade" —one piece of Internet advice in my research on this crude and violent fare was to make sure one got the Swedish version of I Spit on Your Grave because its rape scene was 9 min long as opposed to the other more truncated versions available.

The crucial difference, however between the two kinds of film was the role of the justice system. In the vigilante films the system is temporarily supplanted. Once the evil has been dealt with life, including the functioning justice system, can be resumed. This is a very specific suspension of normality. In the rape-revenge scenarios the system is irrelevant. It provides no initial solace or solution and there is no attempt to avoid its consequences. I Spit on Your Grave simply ends with the

\footnotetext{
51 Heller-Nicholas loc cit Chapter 2.

52 Heller-Nicholas loc cit at 4.

53 Ibid.

54 Henry loc cit at 22.

55 Henry loc cit at 17.

56 Henry loc cit at 181.

57 Marital rape and abuse is covered in The Burning Bed (1984) with Farrah Fawcett; Sleeping with the Enemy (1991) with Julia Roberts and Provoked (2006) with Aishwarya Rai.
} 
rapists all dead. We have no idea what might happen to the victim, writer, Jennifer Hills. $^{58}$

\section{b. Rape-revenge Comedy}

Having found these "gorefests" as beyond my concern with the interface between the legal system and justice because of their crude storylines, lack of stars and noted directors, I was intrigued and stunned to read a film review in the Guardian in March 2017. It concerned the film Elle. The headline of the review was " startlingly strange rape revenge black comedy" 59

Other reviews repeated the notion from Indiewire's "lighthearted rape comedy" ${ }^{\prime 60}$ and other headlines emphasised that this was at least seen as controversial"Robocop director defends his rape comedy" 61 and "Isabelle Huppert stars in controversial rape revenge comedy" 62

It was clear that, along with covering films which I had not covered through lack of skill or ignorance, any further thoughts on this theme would require to assess where and how this new contribution fitted into and/or undermined and altered my thoughts on justice and revenge. Nothing that I had watched had led me to believe that such a product as a "rape-revenge comedy" could exist as being likely or feasible. ${ }^{63}$ The notion was an oxymoron. Even allowing for the "forceful man" trope the idea of comedy and rape did not seem a likely fit.

In many films of the 1950s, however, the "message" from many screen romances and dramas was that women did not initially like to be embraced but that if the man persisted the woman would melt into his arms-waking up the next morning with a glow in their cheeks. I have recently re-watched a number of films where I discover this was no false memory syndrome-Rhett Butler in Gone With the Wind (1939), Tom Donovan in The Quiet Man (1952) and James Bond in Goldfinger (1964) all employ this tactic-even running as far as altering the sexual preferences of the recipient of male attention. The point

\footnotetext{
58 Although she has now been reincarnated in I Spit on Your Grave: Déjà vu (2018)—now a best-selling author living in New York she is kidnapped by the relatives of the victim of her original revengehttp://bloody-disgusting.com/movie/3460592/first-look-official-spit-grave-sequel-deja-vu/ (last accessed April 10 2018). The films I Spit on Your Grave 2 (2013) borrowed the title only-and, of course, the theme; by contrast in I Spit on Your Grave III: Vengeance is Mine (2015) Jennifer seeks revenge while living in Los Angeles. She is played by the actress who played her in the 2010 remake, Sarah Butler, attracted apparently by the film's "feminist edge".

59 Guardian March 92017 available at https://www.theguardian.com/film/2017/mar/09/elle-review-isabe lle-huppert-paul-verhoeven-revenge (last accessed April 10 2018).

60 https://www.indiewire.com/2016/05/cannes-review-paul-verhoevens-elle-is-a-lighthearted-rape-reven ge-story-289023/ (accessed 7 October 2018).

61 https://www.nme.com/news/film/elle-criticism-rape-comedy-paul-verhoeven-2011184 (last accessed 7 October 2018).

62 https://faroutmagazine.co.uk/film-review-isabelle-huppert-stars-in-controversial-rape-revenge-comed y-elle (last accessed 7 October 2018).

63 Pedro Almodovar's first film Pepi, Luci, Bom (1980) technically unites the words "comedy" and "rape" but is located in the parallel universe of Almodovar defying comparison with normal cinema.
} 
here though was that there was no ensuing revenge only gratitude for "masterly" behaviour.

\section{c. Reading a Film with Muted Emotions and Reactions to Rape}

This film that came to my attention as a "rape-revenge comedy" had a cast of noted French actors and furthermore was directed by an award winning and commercially successful mainstream director Paul Verhoeven. The film starts with the rape of the protagonist, Michèle, and ends with a subsequent attempted rape of Michèle, during which the victim's son saves his mother by smashing in the head of the rapist. In the interim the reaction of the rape victim can best be described as muted. She carries on with her life and only some time later calmly announces while out at dinner with friends that she has been raped. The nearest we see to emotion is when she chides her cat for failing to do anything during the rape.

We see Michèle at her work as a successful producer of violent fantasy video games interacting with her young male staff and with her fellow director Anna. We learn that she is concerned about her 70+ mother and her youthful "toy boy" and their plans to marry as well as that her father was responsible many years ago for a mass shooting of 27 people. Michèle is seen quietly assessing whether one of her young male assistants might be the rapist. We see her attracted to the young banker who lives across the street from her house, Patrick. She accepts his help during a storm and she accepts his intimate touch and embrace willingly and is clearly disappointed when he withdraws his hand as if nothing has happened. Michèle is later attacked again by the same ski-masked rapist in her house and manages this time to fight him off as well as reveal him to be the banker Patrick. He flees with a hand stabbed through by Michèle's scissors. Again she does not call the police. Next day they exchange looks as he leaves for work with his hand bandaged. Shortly thereafter, driving back from the prison where her serial killer father has managed to commit suicide, Michèle has an accident on the highway. It is Patrick she calls to rescue her and bandage her bleeding leg. This is a scene shot through with tension as we wonder whether with Michèle in this vulnerable position Patrick will strike again.

Despite her injuries Michèle is prepared to have sex with her lover Robert - the husband of her business partner, Anna with whom she has been having an affair for some time-albeit adopting a passive rag doll like approach which Robert finds stimulating. Again after a dinner with her son and Patrick, Michèle accepts Patrick's invitation to look at his laundry room where he attacks her. Michèle appears to be willing for the sex but Patrick again backs off. He explains that this violence is necessary "C'est necessaire".

Their final encounter takes place shortly after when, Michèle, restored to health celebrates the success of their games company. Michèle takes this opportunity to reveal to Anna that she was the person with whom husband Robert has been having an affair. Michèle leaves in the company of Patrick and when they get to her house he again attacks her. This time, however, he is interrupted by Michèle's son, who interprets the scene as an attempted rape and batters in the 
head of Patrick with a single blow with a log. When last seen the son was still at the celebration party and his appearance at the house is not explained. There is no hint that it is pre-arranged with Michèle. Nor do Michèle's generally fraught relationship and lack of communication with her son suggest that the clubbing of Patrick was a "set up". The film ends with Michèle and Anna walking into the distance with their troubles behind them.

It seems clear that this is not a comedy. It does not seem like it is a rape-revenge film. There is a rape and then there are two further attacks on Michèle. It is far from clear what to make of the last two "attacks". The basement laundry attack seems to be a prelude to consensual rough sex. That is what the last attack also appears to be until the intervention of the son. Those who saw the film and provided the headlines adverted to above clearly did not think so. The fact that this is how the film has been publicised is of significance in seeming to blur the boundaries between revenge and comedy in a wholly surprising context.

\section{d. Assessing the Film in the Light of Its Literary Inspiration}

On subsequent viewings, however, what emerges is that Isabelle Huppert has a mastery of maintaining an enigmatic face indicating little and leaving the audience to make sense of the narrative in whatever way they can. My reading may be false and those of the early critics valid. One approach is to look at the source of the film. Elle was based on a book by the author of Betty Blue, Philippe Djian. Here, in Oh! the same basic plot and characters are found. The major difference which occurred in David Birke's screenplay ${ }^{64}$ was to alter the women's business from a film production company with its descriptions of work time spent reading film treatments to the more visual games environment. One other change, though is replacing the the character's internal monologue with various glacial looks of Isabelle Huppert. The glances replace the voice of Michèle on her experiences and how she perceives them. In the book she knows that there is "nice Patrick" and "rapist Patrick". When in the film she masturbates at her window at the mere sight of Patrick we are not sure which Patrick is turning her on.

After her car accident Michèle is both trying to attract and repel Patrick

I stretch my leg toward him, thus exposing even more of my crotch, ostensibly so he can take a look at my ankle and give me his considered opinion or God knows what. And I wait. I'm ready to blast him with incapacitant agent if I've made a mistake - my Guardian Angel (pepper spray) is under my pillow. My leg is starting to cramp when he decides ${ }^{65}$

There is also an incident in the laundry room when the son Vincent is upstairs asleep when Patrick "jumps” Michèle.

\footnotetext{
${ }^{64}$ David Birke has provided the screenplays for such thrillers as Freeway Killer (2010), 13 Sins (2014) and Slender Man (2018).

${ }^{65}$ Elle (London, Penguin) at 125.
} 
We go sprawling on the floor. Against a man's body, a man's strength, I don't stand a chance. But what spices it up, the thing that would make me smile if I weren't so busy fighting like a madwoman while he tries to get his penis inside me, is that it is within my power to stop this assault in one second, that it is up to me a mere woman, whether or not to send this imbecile slinking back to his nest $^{66}$

Michèle kisses Patrick on his exit from the house and reflects

I'm well aware of all that is sick about what Patrick and I engaged in this afternoon in the laundry room, about that demented relationship, that savage encounter, but I must be honest, I must face the truth. I liked holding his body in my arms, our limbs intermingled, his penis inside me, his wet tongue, his fingers like claws digging into my burning wrists, his hands in my hair, his lips forcing me to open my mouth. I liked all of that. I got off on it, I can't pretend otherwise. I have fantasised about him so many times that I'm only half surprised, but the pure pleasure of it is such a rare prize that I'm still a little stunned $^{67}$

There is also a later encounter in the house when Patrick is apologising for his earlier behaviour in the laundry room

Before I can make a move, he gets one foot inside, presses his lips to mine, and back me up, kicking the door closed behind him, and we are sprawled on the floor in the very spot here he raped me the first time, and we are grunting and groaning and fighting like dogs in an alley.

He pulls up my skirt, rips open my panty hose, and grabs for my genitals while I hammer him with my fists and try to bite him. Then suddenly a veil is torn, the path is lit before me and I immediately stop struggling, lying there inert and consenting just as he is about to do the deed.

He is lying on top of me. He hesitates, stiffens for a second and moans, then collapses like a soufflé. ${ }^{68}$

The prelude to the final attack appears to dispel any "revenge" element. On their return from the party Michèle recounts

A little later, he suggests we stop and do it in the woods because he can't stand to wait any longer..... 69

They decide, however to continue to the house.

I know that screaming is convincing. It expresses the very real rage that wells from deep inside me, drowns me, overwhelms me like some conquering army,

\footnotetext{
66 loc cit at 154 .

67 loc cit at 156 .

68 loc cit at 177 .

69 loc cit at 182 .
} 
yet I know that it also springs from the terrible pleasure I get when I'm with him

He breaks away and tries to get his penis between my legs, struggling like mad, and when he finally manages, when I'm wet and screaming louder and louder, I see Vincent standing behind him and I hear Patrick's skull crack under the pressure of the log with which my son has sent him to meet his maker before I could say boo. ${ }^{70}$

As Michèle reflects, this was an accident rather than a carefully orchestrated revenge scenario. Nowhere in either the book or film version of the story do we get any sense of effective communication between mother and son on any theme. Michèle finds Vincent a sad character who wishes to give his life meaning by looking after his girlfriend's child as if it were his own.

I AM THE ONLY ONE WHO KNOWS THE TRUTH. I'm the only one who knows that the scene was staged and I will carry that secret to me grave. For Vincent, it's infinitely better that way. If he ever learned that he killed a man who was only engaging in the same perverse sex play as his own mother, his currently positive attitude toward me would take a hit ${ }^{71}$

In her assessment going forward after the death of Patrick, Michèle observes

I thank heaven that Patrick really did rape me, at least once, or else the guilt would have driven me $\operatorname{mad}^{72}$

This examination of Djian's text, in one sense, clarifies what is going on but in another it gets us no further forward. It assumes the primacy of the narrative of the base text rather than the much more enigmatic film. Meaning for the majority of people who will watch the film is what the film tells us not what the original author wished to convey-which is, I would suggest, a worrying male fantasy of the secret "joys" of rape and the convergence of rape and "rough sex".

\section{e. Literary Perspectives}

Book and film then are significantly different. As indicated, the film has attracted rather more attention through the acting prowess of Isabelle Huppert as the glacial Michèle and the notoriety of Paul Verhoeven as a director, although Philippe Djian was the author of the book on which the film Betty Blue was based. Looking at this in terms of adaptation theory it is clear that this is no mere transcription but very much a "reimagining",73 and I would argue a very different product.

\footnotetext{
${ }^{70}$ loc cit at 184 .

71 loc cit at 185 .

72 loc cit at 188 .

${ }^{73}$ McFarlane, Brian (1996) Novel to Film: An Introduction to the theory of adaptation (Oxford, Clarendon).
} 
There are also relevant observations on the changing tone of film versions. For instance we find in The Grapes of Wrath a change of its emphasis. The critique of capitalism in Steinbeck's book is "severely muted" in John Ford's film version. ${ }^{74}$ McDougal also makes the perceptive point that film stars bring to any work in which they appear a certain amount of "baggage". 75 Thus we see Isabelle Huppert in Elle with a knowledge of the kind of person she has played in previous films. In addition, in the process of adaptation what is often involved is a simplification and editing down of the original text being adapted.

There are a couple of comments on these observations. Firstly they have a much greater resonance where the book has "heft" and a critical following. Hence we find McDougal writing on the changes to inter alia The Stranger and The Loneliness of the Long Distance Runner which were dealing with well-established literary phenomena. The same cannot be said of Philippe Djian's Oh!. Certainly for the English speaking commentators on the film Elle there was no English translation available until a year after the film was shown. There are no references in the commentaries to the nature of the work which Verhoeven adapted. There is no sense that anyone watching the film has a preconception about Michele's inner voice and her less than passive position in the later assaults of Patrick which we find quite explicitly in Oh!.

Verhoeven is constructing Elle without the literary world looking over his shoulder assessing what kind of job he is making of rendering Djian's text. If they were, it would seem that they might be asking why Michèle is quite so enigmatic in her filmic relations with Patrick. The problem which Alain Resnais noted in relation to adapting novels is, in effect, absent here due to the relative obscurity of the sourceat least for the English language commentators. Resnais indicated that he "would not want to shoot the adaptation of a novel because I think that the writer has completely expressed himself in the novel and that wanting to make a film of it is a little like re-heating a meal". ${ }^{76}$ It would seem that Djian's characters and Verhoeven's differ. The latter though clearly does not share Resnais' reticence at creating his own version or reimagining. ${ }^{77}$

\section{Conclusion}

Returning to my own initial interest on the serious issue of revenge and the specific subgroup of rape-revenge, assessing this film is far from easy. It is, however, a worthwhile undertaking since the idea that a controversial director might have altered what is acceptable in mainstream cinema by treating rape as subject for amusement is not to be ignored. This is a film directed by a man with a screenplay by another man, based on a novel by a third man about the reaction of a woman to being raped. That causes some concern as to how we should view this creation and

\footnotetext{
74 McDougal 1985 at 5.

75 loc cit at 6.

76 quoted in Roy Armes French Cinema since 1946 (1966, London Zwemmer).

77 Another linked approach is to locate it within the canon of work of Paul Verhoeven. Although the auteur approach has its adherents it might caste some light on this work. It does, however, involve a very different task.
} 
how it resonates with audiences. Michèle in both film and book is traumatised by the crimes of her father and the activities of her mother and her son. In the film she seems to be repelled and attracted to a man who rapes her. He gets his just desserts in the end, it seems, by accident. In the interim a feisty woman older dies and a mass murderer commits suicide.

It is not clear why the reviewers chose to characterise this film as a comedy. It is not suffused with comic moments. The director resented its description as a "rape comedy". Verhoeven responded suggesting "It's not a rape comedy at all. It's rape and there is comedy. You're not laughing at all when she gets raped" ${ }^{78}$ I am not sure, either, where the comedy comes in except in the sense that "comedy" is in contrast to tragedy in classical theatre. There also appears to be little to indicate there the death of Patrick is a result of anyone taking revenge for the act of rape. The lesson is, perhaps, to be wary of headlines which may produce controversy for attention. What then is really controversial is the normalisation of the notion of the rape fantasy mentioned above within a mainstream film which does not feature as strongly as one might expect in the responses to the film Elle.

What is clear is that revenge films and rape-revenge films continue to flourish, with The Equalizer 2 and a remake of Death Wish and the fifth iteration of I Spit on Your Grave ${ }^{79}$ on screen in 2018. One set of films is firmly providing fare for multiplexes. The latter continues to appeal to its specialist fan base as well as arguably providing feminist inspiration in the style of Thelma and Louise. ${ }^{80}$ Meanwhile the politics of the women's movement in general and \#MeToo in particular in the entertainment industry engage with the day-to-day reality of exploitation and abuse of women.

Open Access This article is distributed under the terms of the Creative Commons Attribution 4.0 International License (http://creativecommons.org/licenses/by/4.0/), which permits unrestricted use, distribution, and reproduction in any medium, provided you give appropriate credit to the original author(s) and the source, provide a link to the Creative Commons license, and indicate if changes were made.

Publisher's Note Springer Nature remains neutral with regard to jurisdictional claims in published maps and institutional affiliations.

\footnotetext{
78 Paul Verhoeven on Elle: This is not a rape comedy (available at https://www.theguardian.com/ film/2016/may/27/paul-verhoeven-elle-isabelle-huppert-rape-comedy (last accessed 7 October 2018).

79 I Spit on Your Grave: Déjà vu (2018) (dir Meir Zarchi).

801991 (Pathe MGM; dir. Ridley Scott).
} 